\title{
"Therapeutic" serum concentration of phenytoin: the influence of seizure type
}

\author{
DM TURNBULL, MD RAWLINS, D WEIGHTMAN, DW CHADWICK \\ From the Departments of Neurology, Royal Victoria Infirmary, Clinical Pharmacology, and Medical Statistics \\ University of Newcastle-upon-Tyne, Newcastle-upon-Tyne and the Department of Neurology, Walton \\ Hospital, Liverpool, UK
}

SUMMARY Serum phenytoin concentrations were monitored prospectively in 26 patients with previously untreated partial epilepsy, during monotherapy with phenytoin. Only six remained entirely seizure-free, although only four experienced further tonic-clonic seizures. There was no correlation between serum phenytoin concentrations and freedom from partial seizures in those patients in whom such seizures recurred. There did appear to be a correlation between serum phenytoin concentration and freedom from tonic-clonic seizures.

Several authors have attempted to correlate serum phenytoin levels with clinical efficacy. ${ }^{1}$ In spite of a widespread belief to the contrary, a consistent therapeutic range has not been defined, although there is agreement that increasing serum phenytoin levels are generally associated with improved seizure control.

Two important factors might cause variation in a therapeutic range between patients; firstly, differences in the severity of epilepsy, and secondly, the nature of the seizure disorder. The second factor may be of particular importance in view of the poorer prognosis, and lesser responsiveness of partial seizures to anticonvulsant drugs compared to tonic-clonic seizures. ${ }^{23}$

During a controlled randomised comparison of phenytoin and valproate ${ }^{4}$ we have been able to monitor serum phenytoin levels prospectively in adult patients with previously untreated partial epilepsy receiving monotherapy with phenytoin.

\section{Methods}

Patients over the age of 16 years with a history of two or more partial seizures with or without secondary tonic-clonic seizures in the previous three years were commenced on therapy with phenytoin $300 \mathrm{mg}$

Address for reprint requests: Dr DW Chadwick, Walton Hospital, Rice House, Liverpool L9 1AE, UK

Received 19 July 1983 and in revised form 10 October 1983. Accepted 14 October 1983 daily within three months of their last seizure. Patients were followed up at three monthly intervals or more frequently if clinically indicated. At each visit the occurrence of seizures or side effects were documented and the serum phenytoin concentration estimated. If further seizures occurred during follow up, the dose of phenytoin was increased, by $50 \mathrm{mg}$. per day if the previous plasma level was below 10 $\mu \mathrm{g} / \mathrm{ml}$ and by $25 \mathrm{mg}$ per day if the level was greater than $10 \mu \mathrm{g} / \mathrm{ml}$. Increments were administered until seizures were controlled or clinical signs of intoxication occurred irrespective of the serum level.

\section{Results}

Twenty six patients have been followed for between 6 and 36 months (a total of 663 patient-months). Twenty three described complex partial seizures and three simple partial seizures. The small number of patients with simple partial seizures make it impossible to comment on this group separately from those with complex partial symptomatology. Tonic-clonic seizures had occurred in 18 patients. The other characteristics of patients are summarised in table 1 .

We have explored the relationship between seizure control and plasma concentration of phenytoin by relating the occurrence of seizures during a three month period to plasma phenytoin concentration at the commencement of that period.

Table 2 describes data from six patients remaining free of seizures throughout the follow up period, and 20 patients who experienced further seizures after 
Table 1 Patients studied

\begin{tabular}{llllcllllll}
\hline & $\begin{array}{l}\text { Age }(y r) \\
\text { (Median) }\end{array}$ & $\begin{array}{l}\text { Sex } \\
M\end{array}$ & $F$ & $I Q<80$ & $\begin{array}{l}\text { Neurological } \\
\text { Disease }\end{array}$ & $\begin{array}{l}\text { Psychiatric } \\
\text { Disorder }\end{array}$ & EEG & Total \\
\hline Patients & $17-66(34)$ & 16 & 10 & 5 & 7 & 1 & 15 & 11 & 0 & 26 \\
\hline
\end{tabular}

EEG: $\mathbf{N}=$ normal or non-specific abnormality

$F=$ focal abnormality

$\mathbf{G}=$ generalised paroxysmal abnormality

Table 2 Serum phenytoin concentrations in patients with partial seizures

\begin{tabular}{|c|c|c|c|}
\hline & No. patients & No. of 3 month periods & $\begin{array}{l}\text { Serum phenytoin } \\
(\text { Mean } \pm S D) \mu \mathrm{g} / \mathrm{ml}\end{array}$ \\
\hline $\begin{array}{l}\text { Patients without fits } \\
\text { Patients with fits } \\
\text { (a) fit-free periods } \\
\text { b) periods with partial fits } \\
\text { (c) periods with tonic-clonic seizures }\end{array}$ & $\begin{array}{r}6 \\
20 \\
.\end{array}$ & $\begin{array}{r}58 \\
106 \\
51 \\
9\end{array}$ & $\begin{array}{r}11 \cdot 3 \pm 4.06^{*} \\
9 \cdot 6 \pm 6.06 \\
12 \cdot 2 \pm 7 \cdot 4^{*} \\
7.5 \pm 4.23\end{array}$ \\
\hline
\end{tabular}

*Differs from fit-free periods in patients with further fits $p<0.05$.

commencing therapy. In those patients remaining seizure-free, serum phenytoin concentrations were consistently above $10 \mu \mathrm{g} / \mathrm{ml}$ in three, consistently below $10 \mu \mathrm{g} / \mathrm{ml}$ in two, and variable in the final patient. Serum levels from these patients have been excluded from further analysis as it is impossible to compare seizure containing and seizure free periods for these patients.

In those 20 patients with further seizures during the study, serum concentrations of phenytoin were significantly higher in periods during which only partial seizures occurred than in seizure-free periods $(p$ $<0.05)$ ! This paradoxical finding may be explained by more therapy-resistant patients (receiving higher doses of phenytoin, with higher serum levels) contributing more periods to the group of seizure containing periods.

Serum levels of phenytoin were lowest in nine periods (from four patients) in which secondarily generalised fits occurred. The difference between mean phenytoin levels in such periods and those in fit free periods and periods containing only partial seizures was not statistically significant perhaps because of the small number of periods in which tonic-clonic seizures occurred.

We have further examined the relationship between plasma phenytoin concentration and seizure control by comparing mean values from those three month periods in which seizures occurred and those in which they did not, in all 16 patients with partial epilepsy in whom this was possible (fig). (Four patients with further seizures were excluded from this analysis because they had no observed periods which were seizure-free.) We again found a trend towards slightly higher plasma phenytoin levels in periods containing partial seizures only, compared to fit free periods. This difference was not however significant (Students paired $t$ test, $\mathrm{t}=0 \cdot 39$ ). However, serum phenytoin levels were significantly lower in periods containing secondarily generalised fits than in fit free periods $(\mathrm{t}=-3.25, \mathrm{p}<0.05)$.

If there is a clearly defined lower limit to the therapeutic range many patients in the figure should be represented by lines crossing such a lower limit in

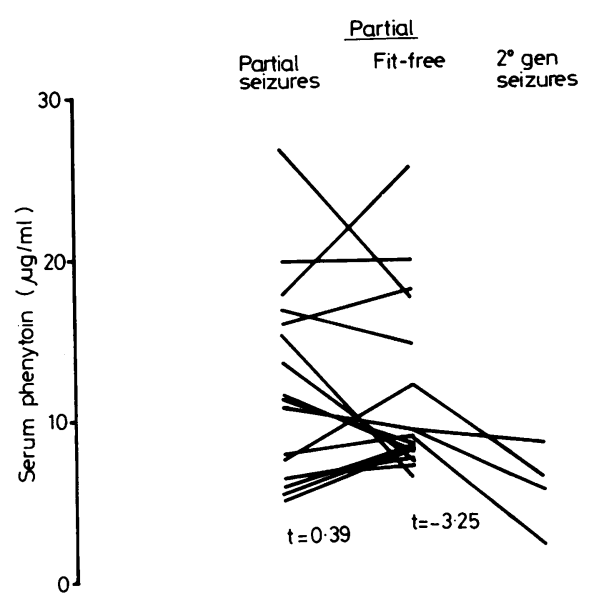

Fig Mean serum phenytoin concentrations for periods containing partial seizures, tonic-clonic seizures, and those entirely free of seizures in 16 patients with partial epilepsies who had periods which contained seizures, and some that did not. Each line represents an individual patient. Mean phenytoin concentrations are significantly lower in periods containing tonic-clonic seizures than in those seizure-free $(t$ $=-3.25, p<0.05)$. 
a direction which passes upward from mean levels during periods containing seizures to mean levels in fit free periods. Such a test would not allow the definition of a lower limit of the therapeutic range at $10 \mu \mathrm{g} / \mathrm{ml}$ as no less then five lines cross such a limit in the wrong direction and only one crosses it in the correct direction. Using these criteria it might be possible to define a lower limit to the therapeutic range against secondarily generalised seizures at a lower level than that conventionally accepted, that is, at between 6 and $8 \mu \mathrm{g} / \mathrm{ml}$.

It was possible to compare the frequency of partial seizures in periods during which 10 patients had plasma levels firstly in the range of $0-9.9 \mu \mathrm{g} / \mathrm{ml}$ (mean frequency 1.53 seizures per month) and then in the range of $10-20 \mu \mathrm{g} / \mathrm{ml}$ (mean frequency $2 \cdot 87$ seizures per month). Five patients had periods firstly in the range of $10-20 \mu \mathrm{g} / \mathrm{ml}$ (mean frequency $4 \cdot 4$ seizures per month) and subsequently in periods with plasma levels greater than $20 \mu \mathrm{g} / \mathrm{ml}$ (mean frequency 2.7 seizures per month). These differences were not statistically significant.

\section{Discussion}

A therapeutic range for phenytoin of $10-20 \mu \mathrm{g} / \mathrm{ml}$ is widely accepted and used in clinical practice. However, the many studies which have attempted to define the relationship between serum concentrations of phenytoin and therapeutic effect are unsatisfactory. ${ }^{6}$ Often they are retrospective, and usually include patients whose epilepsy is resistant to drugs and who are receiving other anticonvulsants. ${ }^{7-10}$ Frequently they compare one group of patients with good seizures control, with a group of patients with poor seizure control; ${ }^{8-11}$ too few studies have studied individual patients during long periods in which they have differing serum levels. ${ }^{12}{ }^{13}$ Often the period of seizure control which is related to an individual serum level is not specified, ${ }^{14}{ }^{15}$ and almost all information relates only to control of tonic-clonic seizures.

In spite of these problems, there is agreement that there is a wide variation in the therapeutic serum levels of phenytoin between individual patients, ${ }^{1}$ and perhaps even within the same patient at differing times. ${ }^{11}$ The present study emphasises this variation, two patients being entirely seizure-free for prolonged periods with relatively low serum levels, possibly reflecting a mild underlying epilepsy.

If a drug is effective in suppressing a particular type of seizure then not only may a large proportion of patients be controlled on an initial dose of the drug, but there should be a striking relationship between the serum concentration of the drug and the presence or absence of seizures in patients in whom seizures recur.

Only six of 26 patients with partial epilepsy remained seizure free and there is a lack of correlation between concentrations of phenytoin and control of partial seizures themselves, in those patients experiencing further fits. Indeed serum levels of phenytoin tended to be higher in periods during which seizures occurred than in seizure free periods. It is impossible to define any clear-cut lower limit to a therapeutic range for phenytoin against this type of seizure. This is in keeping with the finding of Gannaway and Mawer $^{13}$ in chronically treated patients.

Fourteen of 18 patients with tonic clonic seizures prior to treatment had no further such seizures after commencing treatment, but in those four patients who had secondarily generalised fits there was a correlation between the serum level of phenytoin and control of their attacks. Whilst it is difficult to draw a definite conclusion from observations on a small number of patients, if a lower limit to a therapeutic range against this type of seizure were to be defined, this would be between $6-8 \mu \mathrm{g} / \mathrm{ml}$.

Thus in patients with partial epilepsies, phenytoin appears most effective in preventing secondarily generalised fits, although there is no correlation between serum levels of phenytoin and control of partial seizures themselves. In effect, phenytoin's main action would appear to be in suppressing the spread of seizure activity from a primary focus. This reflects the greater resistance of partial seizures relative to tonic-clonic seizures to drug therapy within the same patient. 2415

An absence of correlation between plasma concentration of both carbamazepine,$^{16}$ and valproate ${ }^{17}$ and control of partial seizures has previously been reported. It may be that the present method of study, in defining the relationship of blood levels of anticonvulsants to seizure control, will offer a valid means of comparing the spectrum of efficacy of different anticonvulsant drugs.

In conclusion, this study suggests that the efficacy of serum phenytoin concentrations varies not only between patients, but also with the type of seizure within an individual patient. The concept of a lower limit to a "therapeutic" range, as it is used in everyday clinical practice, should be abandoned as it appears infinitely variable depending on the type and severity of the patient's epilepsy.

We are grateful to Mr JBE Dennis for technical assistance. DMT is in receipt of an MRC Training Fellowship. 


\section{References}

${ }^{1}$ Kutt H. Phenytoin: Relation of plasma concentration to seizure control. In: Woodbury DM, Penry JK, Pippenger CE, eds. Antiepileptic Drugs New York: Raven Press, 1982; 241-6.

${ }^{2}$ Rodin EA. The Prognosis of Patients with epilepsy. Springfield: Thomas, 1968.

${ }^{3}$ Shorvon SD, Reynolds EH. The early prognosis of epilepsy. Br Med J 1982;285:1699-1701.

4 Turnbull DM, Rawlins MD, Weightman D, Chadwick DW. A comparison of phenytoin and valproate in previously untreated adult epileptic patients. J Neurol Neurosurg Psychiatry 1982;45:55-9.

${ }^{5}$ Buchthal F, Svensmark O, Schiller PJ. Clinical and electroencephalographic correlations with serum levels of diphenylhydantoin. Arch Neurol 1960;2:624-70.

- Reynolds EH. Serum levels of anticonvulsant drugs: Interpretation and clinical value. Pharm Ther 1979;8:217-35.

${ }^{7}$ Lund L. Effects of phenytoin in patients with epilepsy in relation to its concentration in plasma. In: Davies DS, Pritchard BNS eds. Biological Effects of Drugs in Relation to their Plasma Concentrations London: Macmillan, 1973;227-38.

${ }^{8}$ Haerer AF, Grace JB. Studies of anticonvulsant levels in epileptics. Acta Neurol Scand 1969;45:18-31.

9 Travers RD, Reynolds EH, Gallagher BB. Variation in response to anticonvulsants in a group of epileptic patients. Arch Neurol 1972;27:29-33.

${ }^{10}$ Borofsky LG, Louis S, Kutt H. Diphenylhydantoin in children. Neurology (Minneap) 1973;23:967-72.

"Schmidt D, Janz D. Thereapeutic plasma concentrations of phenytoin and phenobarbitone. In: GardinerThorpe C, Janz D, Meinardi H, Pippenger CE, eds. Antiepileptic Drug Monitoring. Tunbridge Wells: Pitman, 1977;241-25.

${ }^{12}$ Lund L. Anticonvulsant effect of diphenylhydantoin relative to plasma levels. Arch Neurol 1974;31:289. 94.

${ }^{13}$ Gannaway DJ, Mawer GE. Serum phenytoin concentration and clinical response in patients with epilepsy. $\mathrm{Br}$ J Clin Pharm 1981;12:833-9.

14 Reynolds Eh, Shorvon SD, Galbraith AW, Chadwick DW, Dellaportas CI, Vydelingum L. Phenytoin monotherapy for epilepsy: a long-term prospective study, assisted by serum level monitoring, in previously untreated patients. Epilepsia 1981;22:475-88.

is Shorvon SD, Chadwick DW, Galbraith AW, Reynolds EH. One drug for epilepsy. Br Med J 1978;1:474-6.

${ }^{16}$ Strandjord RE, Johannessen SI. Carbamazepine as the only drug in patients with epilepsy: serum levels and clinical effect. Epilepsia 1980;21:655-62.

17 Turnbull DM, Rawlins MD, Weightman D, Chadwick DW. Plasma concentrations of sodium valproate: their clinical value. Ann Neurol 1983;14:38-42. 